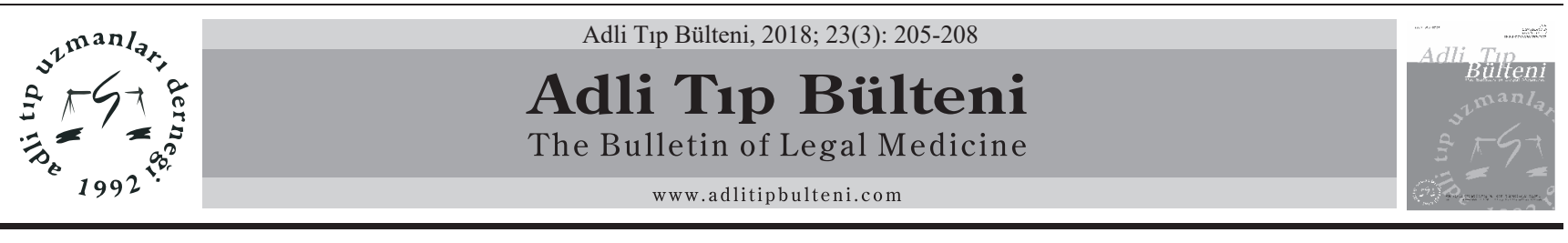

OLGU SUNUMLARI

doi: $10.17986 / \mathrm{blm} .2018345610$

\title{
Adli Tıp Pratiğinde Nadir Görülen Bir Olgu: Dekompresyon Hastalığı
}

\section{Decompression Sickness: A Rarely Encountered Case in Forensic Medicine Practice}

\author{
Orhan Meral', Ahsen Kaya², Ekin Özgür Aktaş \\ ${ }^{1}$ İzmir Bozyaka Ĕgitim ve Araştırma Hastanesi, Adli Tıp Birimi, İzmir \\ ${ }^{2}$ Ege Üniversitesi Tıp Fakültesi Adli Tıp Anabilim Dall, Izmir
}

\begin{abstract}
Özet
"Vurgun" olarak da bilinen "Dekompresyon Hastalığı", basınç altında kan ve dokularda çözünen inert gazın (Nitrojen, Helyum gibi) oluşturduğu kabarcıkların yol açtığı bir durum olup, genellikle dalgıçlarda görülmektedir. Azalan basıncın etkisiyle kanda çözünmüş halde bulunan bu inert gazlar, çözünmüş halden serbestleşerek damar ve dokular içerisinde dokunun beslenmesini engelleyen kabarcıklar oluşturmaktadır. Bu durum tamamen herhangi bir belirti vermeyebileceği gibi, basit bir yorgunluk ve dispneden, parapleji ve hatta ölüme kadar varan geniş bir yelpazede patolojilere de sebep olabilmektedir. Adli Tıp polikliniğine adli rapor istemi ile başvuran, alınan öyküye göre denizde 27 metre derinlikten hızlıca su yüzeyine yükselme sonucu "Dekompresyon Hastalığı" gelişen 41 yaşında erkek olgu, adli tıp pratiğinde nadir görülen bir olgu olması ve bu tür olgulardaki adli tıbbi yaklaşıma dikkat çekilmesi amacıyla sunulmuştur.
\end{abstract}

Anahtar Kelimeler: Dekompresyon Hastalığı; Basınç Değişikliği; Adli Tıp.

\begin{abstract}
Decompression Disease, also known as Caisson Disease, is a condition caused by bubbles formed by inert gases (Nitrogen, Helium, etc.) dissolved in blood and tissues under pressure and is usually seen in divers. These inert gases, which are dissolved by the action of decreasing pressure, come out of solution and form bubbles in vessels and tissues resulting in prevention of tissue nutrition. This condition may produce no symptoms; however, it also may result in a wide range of pathologies from simple fatigue to dyspnea, paraplegia and even death. A 41-year-old male patient who applied to the Forensic Medical Polyclinic with a request for report and developed a "Decompression Disease" resulting from rapid water surface elevation from 27 meters in depth at sea according to the received story is presented as a rare case in forensic medicine practice and to emphasize the forensic medical approach in such cases.
\end{abstract}

Keywords: Decompression Disease; Alterations of Pressure; Forensic Medicine.

\section{Giriş}

Tarihte ilk dalışın tam olarak ne zaman yapıldığı bilinmemekle birlikte, yapılan araştırmalardan insanların M.Ö. 4500-3200 yılları arasında sünger, mercan ve gıda toplayabilmek için serbest dalış yaptığı yönünde veriler elde edilmiştir. Bilinen ilk dalış türü olan serbest dalış, soluk tutularak yapılan, insanların sualtında ancak birkaç dakika kalabilmelerine izin veren ve halen en sık yapılmaktadır. Ayrica SCUBA (Self Contained Underwater Breathing Apparatus) dalışı yüzeyden bağımsız olarak sualtında solumaya olanak sağlayan donanımlarla yapı-

Sorumlu Yazar: Uzm. Dr. Orhan Meral

İzmir Bozyaka Eğitim ve Araştırma Hastanesi, Adli Tip Birimi, İzmir

E-mail: orhanmeral@ymail.com

Geliş: 16.05.2018 Düzeltme: 29.05.2018 Kabul: 04.09.2018 lan, yüzey beslemeli dalış ise sualtında soluma imkânı veren ancak hava desteğinin nargile gibi yüzeyden özel donanımlarla sağlanan daha çok profesyonel dalışlarda kullanılan dalış türüdür (1).

Sualt1, su üstünden tamamen farklı bir ortam olup bu ortamda güvenli bir dalışın gerçekleştirilmesi için dalg1cın temel fizik kanunlarını ve kullandığı havanın özelliklerini çok iyi bilmesi gerektiği, sualtında, su üstünden temel farklılığı oluşturan basınç kavramını anlama ve bilmenin son derece önemli olup, bunun yanı sıra yüzerlilik, 1s1, 1şık ve ses gibi konuların da bilinmesi gerektiği bildirilmiştir (2)

Basınç değişikliği anlamına gelen "Disbarizm"in direkt ve dolaylı etkileri sonucunda insan vücudunda birtakım değişiklikler meydana gelmektedir (3). "Vurgun" olarak da adlandırılan "Dekompresyon Hastalığı" bunlardan biridir $(3,4)$. 
Henry Gaz Kanunu'na göre suyun derinliklerine inme sonucu artan dış basıncın etkisiyle kan ve dokularda bir miktar inert gaz çözünür. Bu gaz, suyun yüzeyine doğru ani yükselme sırasında, çözünmüş inert gazın dışarı atılması için gerekli olan dekompresyon duraklarına uyulmamasına bağlı olarak, kan damarı ve dokularda kabarcıklar oluşturur. Bu durum “Dekompresyon Hastalığı”nın oluşum mekanizması olarak tanımlanmaktadır $(3,5)$.

Derinlik, dip zamanı, çıkış hızı ve dekompresyon zamanı Dekompresyon Hastalığı'nı etkileyen önemli faktörlerdir. Dalınan derinlik, dipte geçen süre ve çıkış hızının fazla olması vücutta çözünen gaz miktarını da aynı oranda arttırmaktadır. Dokularda birikmiş olan inert gazın kabarcık oluşturmaması için dalıcının yüzeye çıkarken belirli derinliklerde beklemesi gerekmektedir. Yap1lan bu beklemelere dekompresyon durağı veya tekniği denilmektedir. Uzun yıllar süren araştırmalar sonucu, günümüzde kullanılan dekompresyon tabloları geliştirilmiştir. Yapılan dalışların dalınan derinlik ve zaman limitlerini gösteren bu tablolara uygun olması halinde vurgun tehlikesinin söz konusu olmadığı bildirilmektedir (2)

Dekompresyon Hastalığının, tıp tarihinde ilk olarak 18. yüzyılın başlarında maden işçilerinde görüldüğü, bu konuda ilk bilimsel tespitlerin, 1878 y1lında Paul Bert tarafından yapıldığı, daha sonraki yıllarda ise basınçlı kabin işçileri, dalgıçlar ve havacı askerlerde de görüldüğü ve 20. yüzyılın başlarından itibaren rekompresyon amaçlı tedavilere başlandığı bildirilmektedir (6).

Dekompresyon Hastalığ 1 , klinik semptomlara göre iki ayrı tipte ele alınmaktadır. Tip 1; eklem ve ekstremite ağrıları ile kaşıntı ve kutanöz dolaşım bozukluklarının, Tip 2 ise; nörolojik ve respiratuar bulguların yanı sıra şok gibi ciddi sistematik tutulumun görüldüğü bir tablodur $(4,7)$.

Dekompresyon Hastalığı ve meydana gelen hava embolizminin tıbbi açıdan hayatı tehdit eden sonuçlara neden olduğu, embolinin nörolojik, kardiyovasküler, ürolojik ve gastrointestinal olarak ciddi hasarlara ve istenmeyen sonuçlara yol açtığ $1(3,4,8,9)$, yine meydana gelen embolinin nihai varış noktasına bağlı olarak mortalite oranının \%714 arasında değiştiği ve dalgıçlar arasında en sık görülen ölüm nedenlerinden biri olduğu belirtilmektedir $(10,11)$.

Dekompresyon hastalığında tedavinin, hastalığın tanındığı anda acil olarak başlatılan ve basınç odası içinde de sürdürülen oksijen ve sıvı tedavisi, basınç odasında uygulanan rekompresyon tedavisi ile kalıcı sekel halinde rehabilitasyon tedavisi olmak üzere üç ana başlıktan oluştuğu (4), rekompresyon işleminin hastaya yüksek basınç kabininde 1 atmosferden daha yüksek basınç altında $\% 100 \mathrm{O}_{2}$ solutularak uygulandığı bildirilmektedir $(6,12)$

Dekompresyona maruz kalma sonucu yaralanan ve adli makamlarca kesin raporunun düzenlenmesi istenen olgu, adli tıp uygulamalarında oldukça nadir görülen bir olgu olması ve bu tür olgulardaki adli tıbbi yaklaşıma dikkat çekilmesi amaciyla sunulmuştur.

\section{Olgu}

Adli Tıp polikliniğine olaydan 27 gün sonra olay mahali görevli Polis Merkezi Amirliği tarafından "taksirle yaralama suçu” açısından adli raporunun düzenlenmesi için gönderilen 41 yaşındaki erkek olgu, deniz patlıcanı ve ahtapot gibi deniz ürünleri toplamak amaciyla 10 yıldır dalgıçlık yaptığını, CMAS 1 yıldız başlangıç seviyesi sportif dalış brövesinin olduğunu, daha önce vurgun öyküsünün olmadığını, olay tarihinde iki kez nargile ile daldığını, ilk dalışında 27 metre derinliğe indiğini, burada 20 dakika boyunca kaldığını, yüzeye 3-4 dakikada çıktığını, 30 dakika dinlendiğini, 2. dalışında da aynı şekilde 27 metre derinlikte 20 dakika kalıp yüzeye 3-4 dakikada çıktığını, her iki çıkışında da tedavi amaçlı su içi rekompresyon uygulamaya çalıştığını, tekneye çıktığında bilincinin açık olduğunu, ancak dakikalar içerisinde baş dönmesi ile görme ve bilinçte bozulmanın meydana geldiğini, arkadaşları tarafından çağırılan ambulans ekiplerince maske ile oksijen verildiğini, bilincinin düzeldiğini, ambulansla 1 saat sonra hastaneye getirildiğini, hastanede iken 1 seans hiperbarik oksijen tedavisi uygulandığını, 6 saat takip edildiğini, şikayetlerinin geçmesi üzerine önerilerle taburcu edildiğini, taburculuk sonrası sağ uylukta uyuşma şikayetlerinin olduğunu, özel bir merkezde her biri 2,5 saatlik 7 seans hiperbarik oksijen tedavisi aldığını beyan etmiştir. Şu anda uyuşmaların tamamen geçtiğini, aktif bir tıbbi şikayetinin olmadığını belirten şahısta tarafımızca yapılan adli muayenede patolojik bulgu saptanmamıştır.

Olgunun olay tarihli tıbbi evrakı incelendiğinde, 112 ekipleri tarafindan 2017 Nisan ayında vurgun iddiasıyla acil servise getirildiği, yapılan muayenesinde; genel durumunun iyi, bilincinin açı olduğu, nörolojik muayenesinin olağan saptandığı, duyu-motor defisit izlenmediği belirtilmiştir. Çekilen tüm vücut BT'sinde; her iki akciğerde apikal bölgelerde ve solda paramediastinal alanda paraseptal amfizem bulgularının, mesane içinde ve pelviste mesane çevresinde yumuşak doku planları arasında hava dansitelerinin izlendiği bildirilmiştir. Venöz hava açısından istenilen Radyoloji konsültasyonunda; bilateral femoral venler (Resim 1 ve 2) ile hepatik ven içerisinde (Resim 3) havanın mevcut olduğu, tedavi protokolü açısından istenilen Sualtı Hekimliği ve Hiperbarik Tip konsültasyonunda; olguya hiperbarik oksijen tedavisi uygulandığ 1 , tedavinin poliklinik şartlarında da devamının önerildiği belirtilmiş, T70.3 Dalgıç Hastalığı (Dekompresyon Hastalığı) ICD-10 kesin tanısı konulmuş, takibinde aktif şikâyet tariflemeyen hastanın önerilerle taburcu edildiği tespit edilmiştir. 
Düzenlenen adli raporda sonuç olarak; vurgun sonucu meydana geldiği belirtilen bu yaralanmanın; "kişinin yaşaminı tehlikeye sokacak nitelikte bir yaralanma oldu$\breve{g u}$ ", "basit bir tıbbi müdahale ile giderilebilecek ölçüde hafif olmadiğl", "Duyularından veya organlarından birinin işlevinin sürekli zaylflamasl ya da yitirilmesi niteliğinde olup olmadiğı hususunun şahsin olay tarihinden 6 (altr) ay sonra müracaat ettirilmesi halinde yapılacak olan muayenesi ile değerlendirilebileceği ” belirtilmiştir.

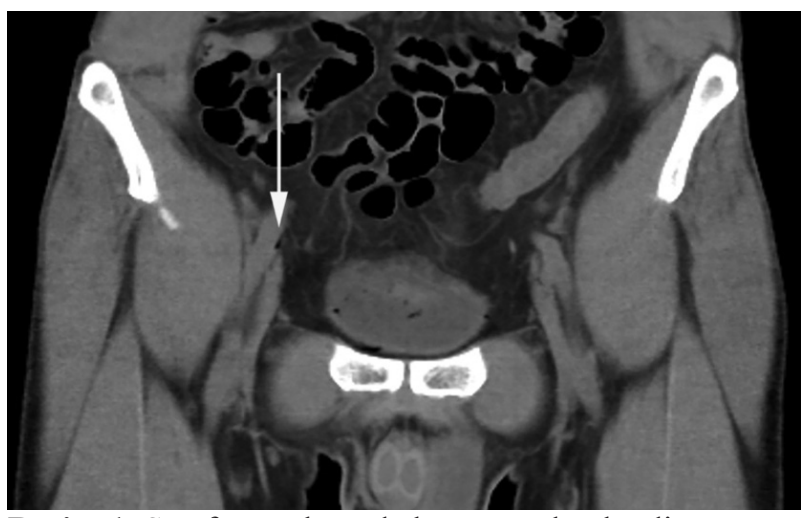

Resim 1. Sağ femoral vende hava görülmektedir.

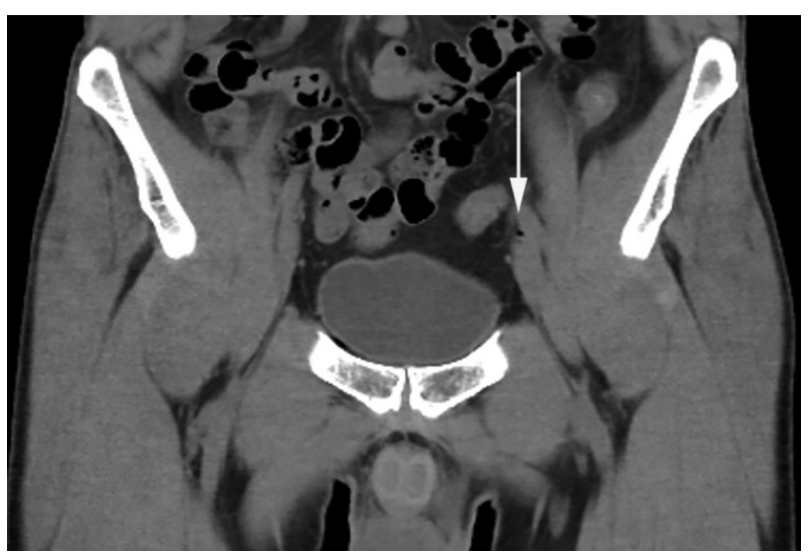

Resim 2. Sol femoral vende hava görülmektedir.

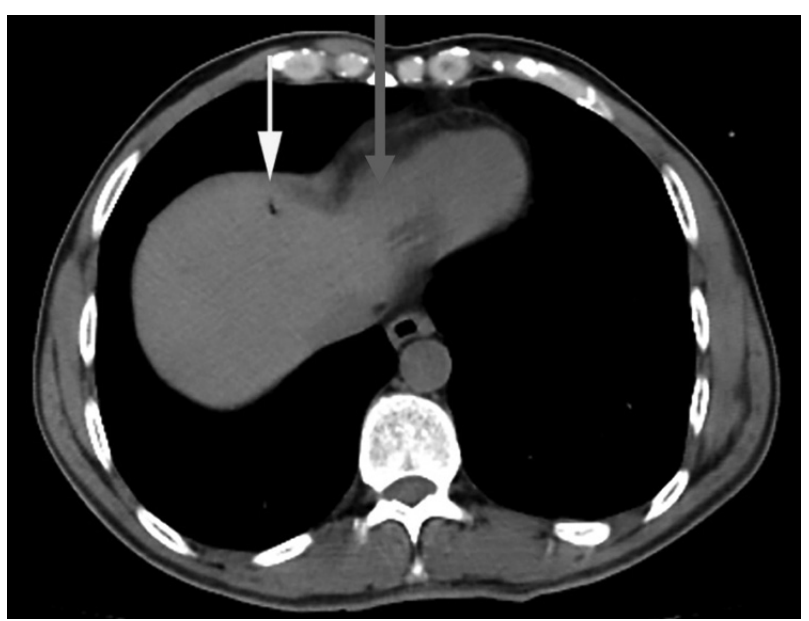

Resim 3. Hepatik vende hava görülmektedir.

\section{Tartışma}

Türk Ceza Kanunu'nda, insan vücudunda suça konu teşkil edebilecek her türlü yaralanmalar "hayata karşı suçlar", "vücut dokunulmazlığına karşı suçlar" ve "işkence ve eziyet" başlıkları altında toplanmıştır. Adli tıbbi uygulamalarda, yaralanmanın orijini (cinai amaçlı, intihar amaçlı veya kaza sonucu) ne olursa olsun, meydana gelen tüm yaralanma (darp, trafik kazası, iş kazası, yanık, elektrik çarpması, cinsel suç, disbarizm-barotravma, zehirlenme, tıbbi uygulama hatası, ihmal ve istismar vb.) olguları adli olgu olarak kabul edilmektedir $(13,14)$.

Adli olgular için düzenlenen kesin raporlarda, Türk Ceza Kanununun ilgili maddeleri uyarınca yaralanma ağırlığının değerlendirilmesi istenmekte olup, bu amaçla tüm ülkede ortak bir dil oluşturulması amacıyla "Türk Ceza Kanunu'nda Tanımlanan Yaralama Suçlarının Adli Tip Açısından Değerlendirilmesi” "isimli kılavuzdan yararlanılmaktadır $(15,16)$. Kılavuzun "Yaşamı Tehlikeye Sokan Bir Duruma Yol Açan Yaralanmalar" başlıklı bölümünde yer alan "Travma sonrası gelişen, klinik bulgu ve tetkiklerle tanisı konan emboliler (trombüs, yağ vb.)" maddesine göre, sunulan olgunun tıbbi evrakında "bilateral femoral ven lümenlerinde ve hepatik venler içerisinde havanin mevcut olduğu" göz önünde bulundurulduğunda saptanan embolinin kişinin yaşamını tehlikeye soktuğu kararına varılmıştır.

Dekompresyon sonucu oluşan gaz embolisinin dolaşımda pihtılaşma sistemine müdahale ederek trombosit agregasyonuna ve yaygın intravasküler koagülasyona, ayrıca miyokard, omurilik ve beyindeki arterioller ile sistemik dolaşımı etkileyerek mikroenfarktlara, hemorajik nekroza ve böylece hayati doku ve organların işlev kaybına neden olabileceği bildirilmiştir $(3,8,9,17)$. Tedavi ile tamamen düzelmiş bir Dekompresyon Hastalığında her hangi bir sekel bırakması beklenmemekle birlikte meydana gelen embolinin olası geç dönem komplikasyonları göz önüne alındığında, dekompresyona maruz kalmış olgularin olay tarihinden en az 6 ay sonra tekrar muayene edilmesi, aradan geçen bu sürede herhangi bir sekel meydana gelip gelmediğinin araştırılması dolayısıyla yaralanmanın duyularından veya organlarından birinin işlevinin sürekli zayıflaması ya da yitirilmesi niteliğinde olup olmadığının değerlendirilmesi açısından önem taşımaktadır.

Sunulan olguda acil serviste yapilan radyolojik görüntüleme tetkiklerine göre, her iki akciğerde apikal bölgelerde ve solda paramediastinal alanda paraseptal amfizem bulgularının, mesane içinde ve pelviste mesane çevresinde yumuşak doku planları arasında hava dansitelerinin izlendiği bildirilmektedir. Ayrıca olguda dalış sonrası görme ve bilinç bozukluğunun ortaya çıktı̆̆ı göze alındığında, her ne kadar olguya Dekompresyon Hastal1- 
ğ1 kesin tanısı konulmuş olsa da mevcut olguda akciğer barotravması/arteriyel gaz embolisinin de ayırıcı tanıda düşünülmesi gerekmektedir. Acil Servis kayıtlarında olguya uygulanan tedavinin detayları belirtilmediğinden, tedavi uygunluğu hakkında yorum yapılamamaktadır.

Yaralanmış bir olguyla karşıllaşılması halinde, "bu kişinin sağllğının bozulmasında başka bir kişinin rolünün olma ihtimali nedeniyle”, mevcut olayın adli olay, kişinin de adli olgu olarak değerlendirilmesi, bu durumun adli makamlara bildirilmesi, adli makamların talebi halinde ise meydana gelen yaralanmanın ağırlık derecesinin belirtildiği adli raporun düzenlenmesi gerekmektedir. Dekompresyon Hastalığı gibi basınç değişikliğine bağlı gelişen yaralanmalar, tüm zorlamalı yaralanmalarda olduğu gibi adli olay olarak ele alınmalıdır (3). Aksi halde sağlık mesleği mensubunun "suçu bildirme" görevini yerine getirmemiş olması ve kanun nazarında "suçu bildirmeme suçu'nun faili olarak yargılanması" söz konusu olabilmektedir. Bunun yanı sıra; kaza bildirim hükümlerini içermesi nedeniyle "Profesyonel Sualtı adamları Yönetmeliği" başta olmak üzere dalış koşullarını düzenleyen tüm mevzuatın da bu kapsamda yeniden gözden geçirilmesi uygun olacaktır.

Sonuç olarak, genel tıp pratiğinde sık karşılaşılmayan bu tabloya adli tıp uygulamalarında da oldukça ender rastlanılmaktadır. Ülkemizde bu tür olgularla ilgili olarak adli tıp literatüründe yeterli veri bulunmamakta olup bu olgu sunumunun genel adli-tıbbi yaklaşım için önemli olduğu düşünülmektedir.

\section{Kaynaklar}

1. Egeren SE. Profesyonel Sualtı adamı Olarak Çalışan Dalgıçların Kişilik Özelliklerinin Değerlendirilmesi, Yayınlanmamış tıpta uzmanlık tezi, 2016; İstanbul.

2. Takıcak O. Sualtı Dalgıçlığında İş Güvenliği Uygulama Esaslarının İncelenmesi, Yayınlanmamış yüksek lisans tezi, 2017; İzmir.

3. Karacaoğlu E, Akcan R, Balseven Odabaşı A, Tümer AR. Disbarizm Kaynaklı Ölüm Olgularında Adli Tıbbi Yakla- şım. Adli Tıp Dergisi, 2011;25(1):41-49

4. Aktaş Ş. Yüksek Basınçla İlişskili Patolojilere Yaklaşım. Yoğun Bakım Dergisi.2005;5(4):208-220

5. Koca E, Demir L, Çakkalkur A, Çelik A, Toklu AS. Uygunsuz Dalış Profili İle Dekompresyon Hastalığına Davet; Olgu Sunumu. 15. Sualtı Bilim Ve Teknoloji Toplantısı Bildiriler Kitabı, 17-18 Kasım 2012;99-104

6. Sen A, Akın A. Dekompresyon Hastalığı. TSK Koruyucu Hekimlik Bülteni, 2004;3(9):221-227

7. Duraklı M, Seçil Y, Yetimalar Y, Başoğlu M. Nöroloji Pratiğinde Az Rastlanan Bir Olgu: Dekompresyon Hastalığı. Journal of Neurological Sciences. 2008;25:(1);37-40

8. Knight B, Saukko PJ, Knight's Forensic Pathology. 3rd ed. New York: Arnold, 2004; p:488-9

9. Mc Mullin AM. Scuba diving: What you and your patients need to know. Cleve Clin J Med 2006;73(8):711-716

10. Türkmen N, Akan O, Cetin S, Eren B, Gürses MS, Gündoğmuş UN. Scuba diver deaths due to air embolism: two case reports. Soud Lek. 2013;58(2):26-8

11. Buzzacott P, Moore JP, Rowley BM, Caruso JL, Nelson C, Denoble PJ, DAN Annual Diving Report 2016 Edition: A report on 2014 data on diving fatalities, injuries, and incidents. https://www.ncbi.nlm.nih.gov/books/NBK424397/

12. Köse A, Altunok G, Dekompresyon Hastalı̆ı (Vurgun), Türkiye Klinikleri Acil Tıp Özel Sayısı, 2018;4(2):127-32

13. Adli Tıp Ders Kitabı, İstanbul Üniversitesi, Cerrahpaşa Tıp Fakültesi, İstanbul, 2011

14. Hekimlik Uygulamalarının Adli Tıbbi Güncellenmesi, Ed: Prof. Dr Gürsel ÇETIN, Uz. Dr. Ahsen KAYA, 2012; İstanbul.

15. Türk Ceza Kanunu. http://www.mevzuat.gov.tr/Metin1. Aspx? MevzuatKod $=1.5 .5237 \&$ MevzuatIliski $=0 \&$ source XmlSearch\&Tur $=1 \&$ Tertip $=5 \& N o=5237$ Erişim Tarihi: 08.01.2018.

16. Türk Ceza Kanunu'nda tanımlanan yaralama suçlarının adli tıp açısından değerlendirilmesi. Editörler: Güzel S, Balcı Y, Çetin G. Güncelleme editörleri: Gündoğmuş ÜN, Balc1 Y, Akın HM. Düzenlenme Tarihi Eylül 2005, Güncellenme Tarihi Haziran 2013.

17. Shkrum MJ, Ramsay DA. Forensic Pathology of Trauma. Humana pres, 2007 